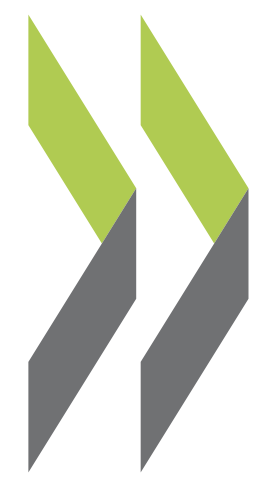

OECD Economics Department Working Papers No. 1312

Estimating the distributional impact of the Greek crisis (2009-2014)

Chrysa Leventi,

Manos Matsaganis 
Organisation de Coopération et de Développement Économiques

Organisation for Economic Co-operation and Development

19-Jul-2016

ECONOMICS DEPARTMENT

English - Or. English

Cancels \& replaces the same document of 05 July 2016

ESTIMATING THE DISTRIBUTIONAL IMPACT OF THE GREEK CRISIS (2009-2014)

ECONOMICS DEPARTMENT WORKING PAPERS No. 1312

by Chrysa Leventi and Manos Matsaganis

OECD Working Papers should not be reported as representing the official views of the OECD or of its member countries. The opinions expressed and arguments employed are those of the author(s).

Authorised for publication by Robert Ford, Deputy Director, Country Studies Branch, Economics Department

All Economics Department Working Papers are available at www.oecd.org/eco/workingpapers

JT03399357

Complete document available on OLIS in its original format

This document and any map included herein are without prejudice to the status of or sovereignty over any territory, to the delimitation of international frontiers and boundaries and to the name of any territory, city or area. 
OECD Working Papers should not be reported as representing the official views of the OECD or of its member countries. The opinions expressed and arguments employed are those of the author(s).

Working Papers describe preliminary results or research in progress by the author(s) and are published to stimulate discussion on a broad range of issues on which the OECD works.

Comments on Working Papers are welcomed, and may be sent to the Economics Department, OECD, 2 Rue André-Pascal, 75775 Paris Cedex 16, France, or by e-mail to eco.contact@oecd.org.

All Economics Department Working Papers are available at www.oecd.org/eco/workingpapers.

This document and any map included herein are without prejudice to the status of or sovereignty over any territory, to the delimitation of international frontiers and boundaries and to the name of any territory, city or area.

The statistical data for Israel are supplied by and under the responsibility of the relevant Israeli authorities. The use of such data by the OECD is without prejudice to the status of the Golan Heights, East Jerusalem and Israeli settlements in the West Bank under the terms of international law.

Latvia was not an OECD member at the time of preparation of this paper. Accordingly, Latvia is not included in the list of OECD countries and is not included in the area totals.

(C) OECD (2016)

You can copy, download or print OECD content for your own use, and you can include excerpts from OECD publications, databases and multimedia products in your own documents, presentations, blogs, websites and teaching materials, provided that suitable acknowledgment of OECD as source and copyright owner is given. All requests for commercial use and translation rights should be submitted to rights@oecd.org 
ECO/WKP(2016)36

\section{ABSTRACT/RÉSUMÉ \\ Estimating the distributional impact of the Greek crisis (2009-2014)}

Estimating the impact of the crisis on income distribution requires up-to-date information. Due to the complexity of income surveys such as EU-SILC, income data usually become available with considerable delay. In this context, micro-simulation models are an appropriate and widely used alternative to bridge the gap in official data, allowing for an early evaluation of the distributional impact of changes in tax-benefit policies and in the wider economy. This paper analyses the effects of the Greek crisis on inequality and poverty in 2009-2014 using the micro-simulation model EUROMOD. Specifically, the paper updates earlier OECD estimates of distributional effects of the crisis in 2009-2012, and provides new estimates for 2013-2014, a period for which survey data are not yet publicly available. The results indicate that inequality, as measured by most indicators, rose in 20102013 as the recession deepened and unemployment rose, and fell back in 2014 as the economy stabilised. Relative poverty seems to have increased in 2012, after remaining broadly unchanged in the previous two years; in 2013 it appears to have stabilised, while in 2014 it fell back to only slightly above its level in 2010 (13.8\% vs.13.2\% respectively). This pattern is more pronounced when poverty is measured against an "anchored" benchmark: the proportion of population whose income fell below a poverty line anchored in pre-crisis terms increased steadily and steeply, until 2014 when it finally stabilised at $27.4 \%$ (from $13.2 \%$ in 2010 ). Not all population groups were affected evenly by recent developments: the rise of poverty in 2010-2013 especially affected the unemployed, the self-employed, the young, the middle-aged, families living in Athens, families paying rent or mortgage rather than outright owning their dwelling; on the contrary, relative poverty actually fell among groups traditionally seen as 'poor', such as farmers and the elderly - although in the latter case the relative improvement in terms of income may have been offset by difficulties in access to health care. The paper also assesses first-round effects of austerity policies on the income distribution given changes in the wider economy, i.e. abstracting from second-round effects associated with the deflationary impact of austerity on output. In this sense, early austerity policies per se appear to have had a small positive distributional impact, partly offsetting the increases in inequality and poverty due to the recession. As fiscal consolidation intensified in 2012, tax and benefit policies appear to have exacerbated the adverse distributional effects of the recession, causing poverty and inequality to rise further. From 2013, austerity policies seem to have had a more equalizing effect, especially at the bottom of the distribution and in terms of its distance from the top.

This working paper relates to the 2016 OECD Economic Survey of Greece (www.oecd.org/eco/surveys/economic-survey-greece.htm).

JEL Classification: D31; D63; E62; H22; I32; I38.

Keywords: Greece; labour market; inequality; poverty; distributional impact; taxation

***********************************

\section{Estimer les effets de la crise grecque sur la distribution des revenus (2009-2014)}

La présente étude s'appuie sur des modèles de microsimulation afin d'actualiser les estimations réalisées par l'OCDE quant aux effets de la crise sur les inégalités et la pauvreté en Grèce en 2009-2012, et en produire de nouvelles pour 2013-2014. À l'aune de la plupart des indicateurs utilisés pour les mesurer, les inégalités se sont creusées en 2010-2013 parallèlement à l'aggravation de la récession et à la montée du chômage, pour reculer ensuite en 2014 à la faveur de la stabilisation de l'économie. Le taux de pauvreté relative semble avoir augmenté en 2012, après être resté globalement inchangé au cours des deux années précédentes. Il s'est ensuite stabilisé en 2013 pour retomber, en 2014, en deçà du niveau de 2012. Cette tendance est encore plus marquée lorsque la pauvreté est mesurée par rapport à un seuil «ancré ». Toutes les populations n'ont pas été touchées dans les mêmes proportions par l'aggravation de la pauvreté relative : la montée de la pauvreté en 2010-2013 a particulièrement touché les chômeurs, les travailleurs indépendants, les jeunes, les personnes d'âge moyen, les ménages résidant à Athènes, et les ménages qui paient un loyer ou remboursent un prêt immobilier. À l'inverse, la pauvreté relative a en fait reculé parmi les populations traditionnellement considérées comme «pauvres", comme les exploitants agricoles et les personnes âgées - même si, pour ces dernières, l'amélioration relative des revenus pourrait avoir été compensée par des difficultés d'accès aux services de santé. Il semble que les politiques d'austérité en elles-mêmes (hors effets de l'assainissement budgétaire sur la production) ont eu un modeste impact sur les inégalités et la pauvreté relative dans un premier temps, atténuant en partie les effets de la récession. Avec l'intensification de l'effort d'assainissement des finances publiques en 2012, les politiques fiscales et sociales semblent avoir favorisé une hausse de la pauvreté et des inégalités. Depuis 2013, les mesures d'austérité semblent avoir contribué à réduire les inégalités, surtout au bas de l'échelle de distribution des revenus et en termes d'écart entre le bas et le haut de la distribution. La part de la population dont le revenu est tombé sous le seuil de la pauvreté ancrée avant la crise a augmenté avec chaque cycle de mesures d'austérité, et la hausse régulière du chômage n'a fait qu'amplifier le mouvement, jusqu'en 2014 lorsqu'elle a fini par se stabiliser.

Ce Document de travail se rapporte à l'Étude économique de l'OCDE de la Grèce 2016 (www.oecd.org/fr/eco/etudes/etude-economique-grece.htm).

Classification JEL : D31; D63; E62; H22; I32; I38.

Mots clés : Grèce; marché du travail; inégalité; la pauvreté; impact distributif; imposition 
Estimating the distributional impact of the Greek crisis (2009-2014) ..........................................................5

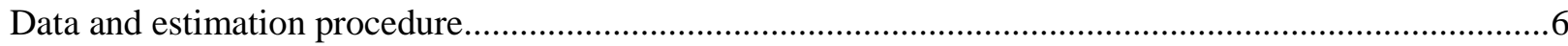

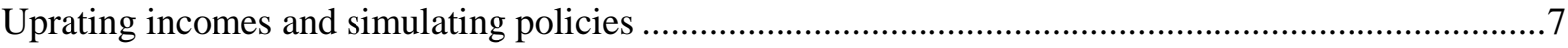

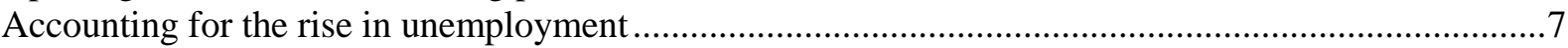

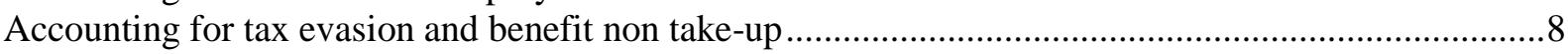

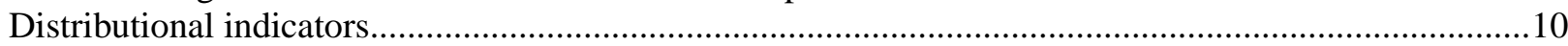

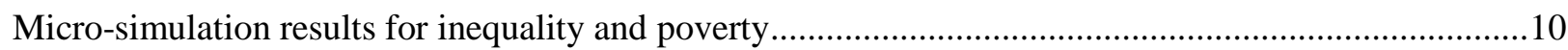

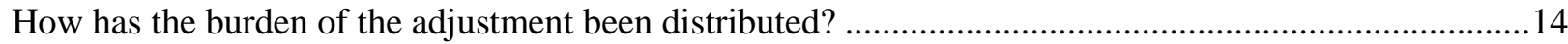

Distinguishing the effects of consolidation policies from recession ....................................................14

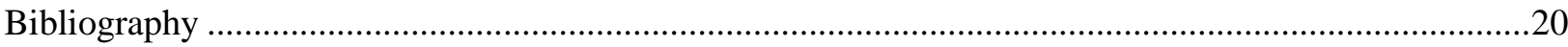

Annex A1 Fiscal consolidation policies in Greece (2010-2014)...................................................................21

Annex A2 EUROMOD uprating factors and labour market adjustments ...............................................26

\section{Tables}

1. Estimated Inequality and poverty indices over the period 2009-14 .....................................11

2. Relative poverty rates among population groups …............................................................12

3. Relative poverty rates among population groups .................................................................

4. Disaggregating the first-order effects of fiscal consolidation and the wider recession ...............15

5. Identifying the effect of individual policies on inequality....................................................... 16

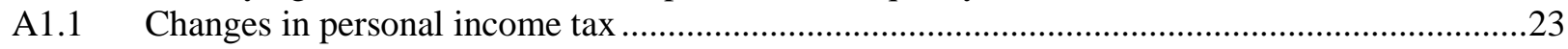

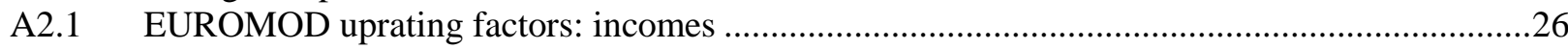

A2.2 EUROMOD uprating factors: assets and expenditure items ............................................26

A2.3 EUROMOD uprating factors: non-simulated social benefits .................................................27

A2.4 Effect of labour market adjustments on employment rates $(2009-2014)$...................................2

\section{Figures}

1. Changes in relative income shares since the onset of the crisis ..............................................11

2. Change in household disposable income due to consolidation, 2010 and $2011 \ldots \ldots \ldots \ldots \ldots \ldots \ldots \ldots . . . .17$

3. Change in household disposable income due to consolidation, 2012 and 2013 _......................18

4. Change in household disposable income due to consolidation, 2014 .......................................20

\section{Boxes}

1. Advantages and drawbacks of micro-simulation models..................................................................

2. Estimating the distributional effects of fiscal consolidation versus recession ................................14 
ECO/WKP(2016)36

\title{
Estimating the distributional impact of the Greek crisis (2009-2014)
}

\author{
By Chrysa Leventi and Manos Matsaganis ${ }^{1}$
}

This paper updates earlier OECD estimates of the effects of the crisis on inequality and poverty in Greece in 2009-2012 (Koutsogeorgopoulou et al., 2014), and provides new estimates for 2013-2014. As the paper uses a more recent wave of the European Union Statistics on Income and Living Conditions (EU-SILC) $^{2}$, from the year 2010 (reporting on 2009 incomes), the results shown here do not exactly replicate those of the earlier study for 2009-2012. Specifically, starting points are somewhat different, although trends over time are very similar.

The distributional effects of the crisis discussed here are derived using EUROMOD, the European Union tax-benefit microsimulation model. The model combines information from income surveys with the rules of the tax and benefit system to simulate tax liabilities and benefit entitlements of households. Its basic output is the micro-level change in household income due to policy changes (Sutherland, 2001). EUROMOD has been used for numerous applications, at a country or, EU-level, including the examination of the redistributive effects of tax-benefit policies, specific aspects of tax design (for example, housing taxation across Europe) and work incentives and labour supply, providing thereby a valuable tool for policy analysis (Sutherland and Figari, 2013). The use of the micro-simulation technique has important advantages, but also limitations (Box 1).

1 Chrysa Leventi is Senior Research Officer at the Institute for Social and Economic Research, University of Essex, and Research Associate of the Policy Analysis Research Unit, Athens University of Economics and Business. Manos Matsaganis is Associate Professor at Department of Architecture and Urban Studies, Politecnico di Milano, and Co-ordinator of the Policy Analysis Research Unit, Athens University of Economics and Business. The authors would like to thank Herwig Immervoll (Senior Social Policy Economist, OECD directorate for Education, Learning and Skills) and Piritta Sorsa (Head of Division, OECD Economics department) for valuable comments on earlier drafts. Anthony Bolton provided administrative assistance.

2. At the time of writing, SILC 2012 (2011 income data) was also available for use in the Greek version of EUROMOD. Nevertheless, it was rejected in favour of SILC 2010 (2009 income data) on the grounds that the latter is the only dataset that can cover the whole period in question (i.e. 2009-2014), whereas using SILC 2012 would limit the scope of analysis to 20112014 alone. Moreover, the labour market adjustments required so that SILC 2012 reflects changes in the labour market in 2012-2014 were still being tested by EUROMOD developers in ISER Essex, which makes using SILC 2010 (where labour market adjustments have been thoroughly checked) a better and safer option. 


\section{Box 1. Advantages and drawbacks of micro-simulation models}

Estimating the impact of the crisis on income distribution requires up-to-date information. Due to the complexity of income surveys, income data become available with considerable delay. For instance, survey data on incomes earned in 2014 will be released only in 2017 . In this context, micro-simulation models are an appropriate, and widely used, alternative to bridge the gap in official data, allowing for an early evaluation of the distributional impact of the Greek crisis in 2009-2014.

In addition to providing timely information, micro-simulation allows to distinguish changes in the income distribution, to attribute them to specific market developments (such as the rise in unemployment), and to identify the impact of key government policies (such as changes in personal income tax or cuts in pensions), taking into account the complex ways in which taxes interact with benefits, and with market incomes.

There are, however, some methodological limitations in micro-simulation techniques that need to be taken into account when reading the results:

- $\quad$ First, under standard practice, micro-simulation provides estimates of first-order distributional effects of policy changes, ignoring second-order behavioural responses (e.g. linked to consumption or labour supply). If such behavioural responses are significant, this will affect estimates of distributional effects. Furthermore, broader interactions between fiscal consolidation and output (e.g. causing reductions in labour demand) are also being left out (see Box 2).

- Secondly, in the absence of up-to-date income data, a "synthetic" income distribution has to be created taking into account tax and benefit rules and labour market changes over the period of consideration (see below). Given that the synthetic distribution simplifies income dynamics, results may under- or over-estimate actual changes.

\section{Data and estimation procedure}

The information base of EUROMOD comprises the tax-benefit rules and a representative set of micro-data. The Greek micro-data underlying the current analysis are drawn from the 2010 cross-sectional European (UDB) and the national (PDB) versions of EU-SILC. The database provides multidimensional information on income distribution and social inclusion. Using the PDB version allows one to exploit more detailed information collected in the national questionnaire.

Since official income data are published only with a lag, a synthetic income distribution was created to analyse the distributional impact of crisis based on the following steps: $i$ ) simulating 2009-2014 tax and benefit policies in order to be able to calculate their (direct) effect on household incomes; ii) uprating the dataset's underlying incomes, from EU-SILC's income reference period (2009) to the latest policy year (2014); and iii) accounting for the rise in long-term and short-term unemployment ${ }^{3}$. The first two steps i.e. simulating current policies on updated incomes - are part of the standard functionality of EUROMOD (and they are discussed here together). In view of the sharp rise in unemployment since the onset of the crisis, however, the current analysis also takes into account changes in the labour market characteristics of the population covered by the survey, thereby going beyond the standard practice in micro-simulation. In addition, estimates take into account tax evasion, which is important in the Greek context, improving the accuracy of the results. More information on creating the synthetic income distribution for Greece in 2009-2014 is provided below.

3. Changes in inactivity (non-participation in the labour force) are ignored here. Labour Force Survey data show that in the five years between $2009 \mathrm{q} 2$ and $2014 \mathrm{q} 2$ the inactivity rate rose from $35.0 \%$ to $39.8 \%$. Over the same period, the unemployment rate went from $7.2 \%$ to $26.6 \%$ (total population aged $15+$ ). 


\section{Uprating incomes and simulating policies}

The calculation of the disposable household income (for each household in the sample) in EUROMOD is made up by two elements: income that is stimulated by the model and income taken from the survey data (for example, earnings) (Jara and Leventi, 2014). This involves simulating tax-benefit policies and uprating the non-simulated income sources beyond the income data reference period (that is, beyond 2009) using factors based on available statistics.

With respect to the first step in the present analysis the Greek tax-benefit system was simulated for every single year from 2009 to 2014. All consolidation policies (described in the Annex A.1) were simulated directly by EUROMOD apart from changes in indirect taxes as the EU-SILC database does not provide information on consumption. On the other hand, the analysis does not take into account changes in the provision of social benefits in kind (publicly-funded health care, elderly care, education, childcare, and so on). While commendable progress has been made towards incorporating non-monetary components into EUROMOD, the relevant module is not available yet (see Paulus et al, 2010).

Regarding the updating of non-simulated income sources:

- Original incomes were uprated on the basis of the Bank of Greece estimates (2015 and previous) of average rates of earnings growth of employees by category in 2009-2014 (Table A2.1). Incomes from self-employment were assumed to move in line with average incomes in the entire economy given the lack of reliable data on the earnings growth for this group. In the case of farmers, earnings were uprated on the basis of data on gross value added by industry (ElStat, 2015). Finally, assets and expenditure have been uprated on the basis of the most reliable information available (Table A2.2).

- Social benefits that are not simulated in EUROMOD, either because they are beyond the scope of the model or due to the lack of the necessary information, were uprated on the basis of actual changes in rates or evolution of average payments (Table A2.3).

\section{Accounting for the rise in unemployment}

There are two main methods for accounting for changes in employment status. The first is a static approach. It involves a re-weighting of the EU-SILC sample by increasing the weights of households containing unemployed workers at the time of the survey, while reducing the weights of other households to hold constant the composition of the dataset (Immervoll et al., 2006). The second method introduces an element of dynamic change in micro-simulation by explicitly modelling labour market transitions at individual level. Specifically, this paper models transitions from employment to short-term unemployment, and from short-term to long-term unemployment (or vice versa).

A drawback of the re-weighting method is that it implicitly assumes that the characteristics of those losing their job at the onset of the crisis are similar to those already unemployed at the time of the survey, which can be quite misleading in the case of Greece (Leventi and Matsaganis, 2013). There has been, for example, a large increase in the unemployment rate of prime-age since 2010 - a traditionally protected group of workers.

The current analysis builds on the second approach. Drawing on the work of Rastrigina et al. (2015) the rise in unemployment was accounted for by modifying the employment status of a certain number of observations in the EUROMOD input data. This 'nowcasting' approach can be briefly summarised as follows. Observations are selected on the basis of conditional probabilities of being employed. A logit model is used for estimating a 'risk score' for working age (16-64) individuals in the EUROMOD input 
data. The model is estimated separately for individuals with higher and lower levels of education, to allow for structural differences in the labour market situation of the two groups. The weighted total number of observations that are selected to go through transitions based on their probabilities corresponds to the relative net change in employment levels by age group, gender and education (a total of 18 categories) as shown in the macro level Labour Force Survey (LFS) statistics. Changes from short-term to long-term unemployment are also modelled based on a similar selection procedure as the one described above.

Table A2.4 shows the effect of adjustments on employment rates. The small difference in the initial (i.e. 2009) employment rates in EUROMOD (i.e. in SILC-based input data) relative to LFS data is mainly due to differences in the structure of the underlying working-age populations (as projected from the different samples of the two surveys), and also to differences in the way labour market status is measured in the two surveys. Hence, the aim of this adjustment is not to match the EUROMOD and LFS employment patterns in absolute terms but to account for relative changes in employment levels. Labour market characteristics and sources of income are re-calculated for those observations that are subject to transitions. In particular, employment and self-employment income is set to zero for individuals moving from employment into unemployment ${ }^{4}$; for individuals moving from unemployment into employment, earnings are set equal to the mean of those already employed within the same category (as defined by age, gender and education) ${ }^{5}$.

\section{Accounting for tax evasion and benefit non take-up}

Tax evasion adjustment was made on the basis of available estimates of income under-reporting by income source. In particular, based on Leventi et al. (2013), the rates applied were set to 5\% for salaries and wages, $35 \%$ for self-employment earnings and $80 \%$ for farming incomes. On the assumption that net incomes reported in SILC reflect true incomes, that is, individuals reveal their real total net income to survey interviewers, the individuals' real gross income (which includes the part of income which is not reported to the tax authorities) have been calculated as follows:

$$
\mathrm{G}_{i}=\mathrm{N}_{i}+\mathrm{T}\left(\left(1-\mathrm{r}_{i}\right)^{*} \mathrm{G}_{i}\right)
$$

where:

$i=$ employment income, self-employment income, farming income;

$\mathrm{N}_{i}$ denotes individuals' real net income;

$\mathrm{G}_{i}$ denotes individuals' real gross income

$\mathrm{r}_{i}$ is the rate of income under-reporting; and

$\mathrm{T}\left(\mathrm{G}_{i}, \mathrm{r}_{i}\right)$ the personal income tax function in the presence of tax evasion.

4. As explained earlier, the paper separately models changes from employment to short-term unemployment, and from short-term to long-term unemployment. This transition is critical due to its implications for eligibility for, and receipt of, unemployment benefits. In 2014, the coverage rate for contributory unemployment insurance benefit (max. duration: 12 months), though low $(37 \%)$, was significantly higher than the coverage rate for non-contributory unemployment assistance benefit, catering for the long-term unemployed (4\%).

5. Since most workers making the transition from unemployment to employment are likely to earn less than they did before they lost their job, the method applied here may understate the true extent of earnings dispersion (and income inequality). However, since such transitions were relatively rare in Greece in 2009-2014 (unlike those in the opposite direction, i.e. from employment to unemployment), the resulting bias is probably small. 
By solving this recursive problem iteratively and for each income source separately, one can obtain the values of real gross income, $\mathrm{G}_{i}$, with the rates of under-reporting used to separate the reported from the unreported part of gross income. EUROMOD treats the former as subject to income tax and social insurance contributions (and as used in resource assessment for means-tested benefits), while it adds the latter to individuals' disposable income.

As for the correction of benefit non take-up, this was carried out for three income-tested benefits: social pension, aimed for people aged over 65 with insufficient contributions for a social insurance pension; unemployment assistance, a non-contributory programme targeted at long-term unemployed workers in low-income families (Leventi and Matsaganis, 2013); and social dividend, an means-tested benefit paid as a lump sum to poor households in 2014.

\section{Distributional indicators}

The main distributional (income and poverty) measures used in the analysis are:

\section{- $\quad$ Income inequality}

- Gini coefficient. Measures the extent to which income distribution among individuals or households deviates from a perfectly equal distribution (OECD, 2013). The Gini index is probably the most popular summary statistic of inequality as it is widely available due to its easy computation and comparability across countries and over time. A zero coefficient characterises perfect equality, whereas a coefficient of one represents perfect inequality, that is, all income is held by one individual or household. At the same time, the Gini has well documented drawbacks: two very different distributions, and thus different inequality patterns, may yield the same Gini coefficient (see, for example, Bellù and Liberati, 2006); and the Gini is more sensitive to changes in the middle of the income distribution, rather than the extremes which are of more interest from a social welfare perspective (see, for example, Atkinson, 1970).

- $\quad$ The inter-decile share ratio S90/S10. It is the ratio of the equivalised disposable income of the $10 \%$ richest of the population to the poorest $10 \%$.

- $\quad$ The inter-quintile share ratio S80/S20. It is the ratio of the average equivalised disposable income of the $20 \%$ richest of the population to the poorest $20 \%$. The last two measures focus on the tails of the income distribution.

- $\quad$ Poverty indicators. Poverty measures are based on income thresholds (poverty lines) determined in absolute or relative terms. To facilitate and guarantee cross-country consistency, the OECD uses relative and "anchored" poverty lines based on observed equivalised household median disposable income:

- $\quad$ Relative poverty. The share of people living in households below a relative threshold of income, often under $50 \%$ of median disposable income. Disposable income is "equivalised" by dividing it by the square root of household size to adjust for economies of scale in household spending.

- "Anchored" poverty. The poverty line is fixed at 50\% of median equivalised household disposable income in a base year (2005, in this chapter) adjusted for inflation. This has some characteristics of an absolute measure, although it is sensitive to the choice of the base year.

\section{Micro-simulation results for inequality and poverty}

The micro-simulation results indicate that inequality, as measured by most indicators, rose in 2010-2013 as the recession deepened and unemployment rose, and fell back in 2014 as the economy stabilised (Table 1). The various indicators suggest that changes were more significant at the two ends (especially the lower end) of the income distribution, than around the middle. 
Analysis of the changes in relative income share by decile provides further support to this finding (Figure 1). The poorest $10 \%$ of population lost 1.1 percentage point of their share in total household disposable income between 2009 and 2013, followed by the second decile ( 0.2 percentage point), while the top decile gained close to 0.7 percentage point (and deciles 8 and 9 around 0.3 percentage points). All remaining deciles saw their relative position change little (up to \pm 0.6 or less). ${ }^{6}$

Table 1. Estimated inequality and poverty indices over the period 2009-14

\begin{tabular}{lrrrrrr}
\hline & $\mathbf{2 0 0 9}$ & $\mathbf{2 0 1 0}$ & $\mathbf{2 0 1 1}$ & $\mathbf{2 0 1 2}$ & $\mathbf{2 0 1 3}$ & $\mathbf{2 0 1 4}$ \\
\hline Income inequality & & & & & & \\
\multicolumn{1}{c}{ Gini index } & 0.326 & 0.332 & 0.336 & 0.346 & 0.349 & 0.342 \\
S80/S20 income decile ratio & 5.4 & 5.7 & 5.9 & 6.7 & 6.8 & 6.5 \\
S90/S10 income decile ratio & 8.9 & 9.8 & 11.1 & 14.1 & 15.3 & 14.3 \\
\hline Relative poverty & 12.4 & 13.2 & 13.1 & 14.7 & 14.8 & 13.8 \\
\hline "Anchored"poverty & & 13.2 & 18.5 & 24.5 & 29.3 & 27.4 \\
\hline
\end{tabular}

1. Based on micro-simulation analysis.

2. The poverty line is $50 \%$ of median equivalised disposable income in each year.

3. The poverty line is fixed at $50 \%$ of median equivalised household disposable income in 2005 .

Source: EUROMOD estimates.

In 2014, the trend towards greater income dispersion was partly reversed: top decile lost over 0.3 percentage point of its relative income share, while the poorest $30 \%$ of population gained between 0.1 and 0.17 percentage points.

6. Note that the above are expressed in terms of relative income share. In absolute terms, the poorest decile by 2013 had lost $63.3 \%$ of its average income in 2009 (in real terms), while the richest decile had also lost, though less (37.0\%). Note also that the composition of deciles is not fixed (acknowledging the fact that, as a rule, membership of the poorest $10 \%$ of population will be partly different each year). Matsaganis and Leventi (2014) reported a very similar pattern (although the actual figures were slightly different, given that the paper had applied Eurostat equivalence scales). 
Figure 1. Changes in relative income shares since the onset of the crisis

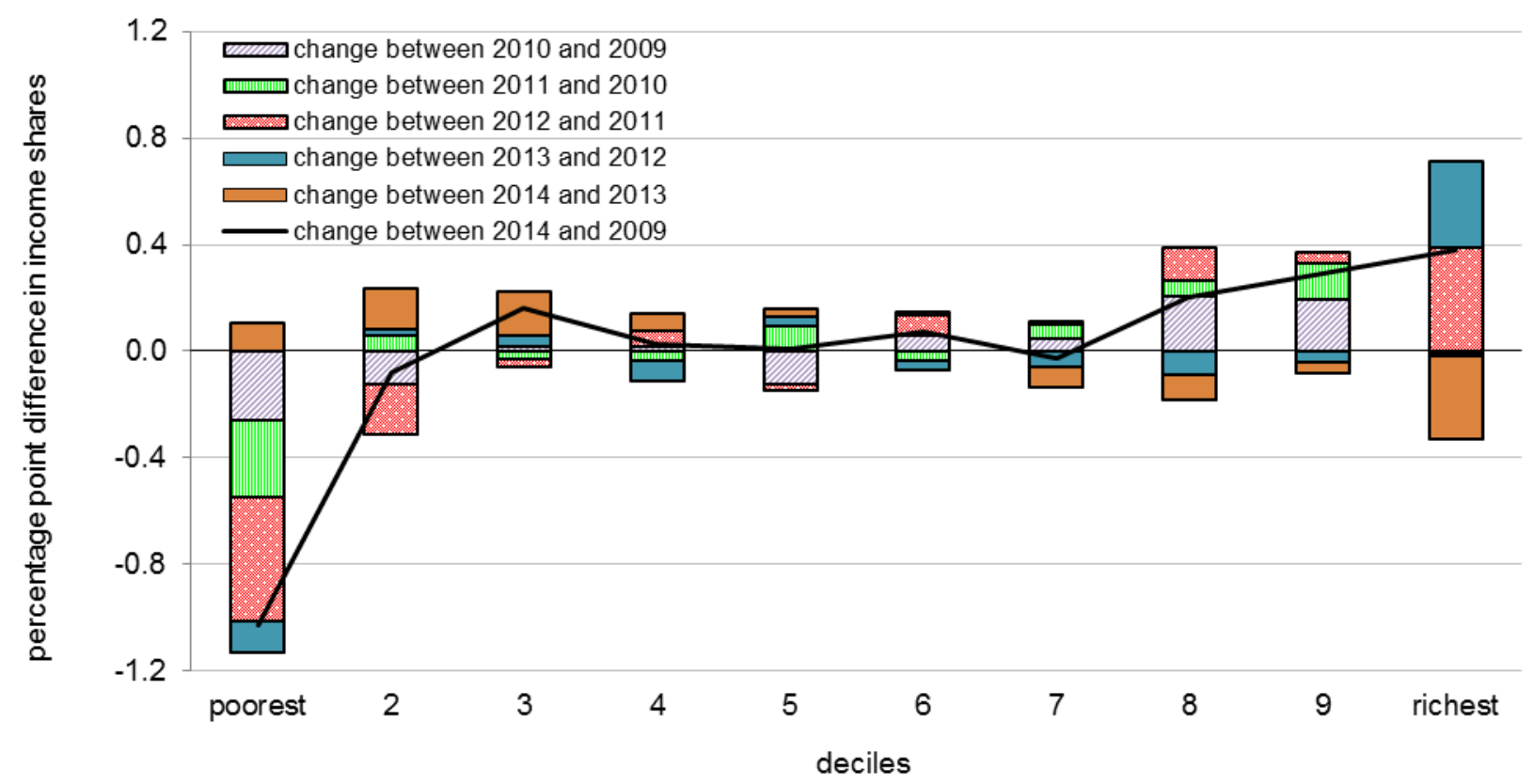

1. Income deciles were constructed according to OECD equivalence scale (i.e. square root of household size). Household disposable income is defined as total income, from all sources, of all household members, net of taxes and social insurance contributions. Note that the composition of deciles is not fixed.

Source: EUROMOD estimates.

Relative poverty (50\% of median equivalised income) seems to have increased in 2012, after remaining broadly unchanged in the previous two years (Table 2). In 2013 it appears to have stabilised, while in 2014 it fell below its level in 2012. Clearly, by construction relative poverty rates are obtained by reference to a moving threshold. In this case, that threshold decreased sharply in 2009-2013 (by 33\% and $37 \%$ in nominal and real terms respectively).

When poverty is measured against an "anchored" benchmark (here: half the median real incomes observed in 2005), the pattern seen above - poverty rising in 2009-2013, and falling in 2014 - is more pronounced (Table 3). This is not surprising, however, given the sharp adjustment of the economy since 2009.

Not all population groups were affected evenly by the rise in relative poverty. According to microsimulation results, the rise of poverty in 2010-2013 impacted especially the unemployed, the self-employed, the young (18-29 years), the middle-aged (45-64 years), families living in Athens and those paying rent or mortgage (rather than outright owning their dwelling).

Relative poverty also increased significantly among groups experiencing below-average poverty rates, such as the liberal professions and, to a lesser extent, public or bank employees. The same was true in the case of university graduates, whose relative poverty risk more than doubled, although remained lower than that for persons with a lower level of educational attainment. On the contrary, relative poverty actually fell among groups traditionally seen as 'poor', such as farmers and the elderly - although in the latter case the relative improvement in terms of income may have been offset by difficulties in access to health services (Table 2). 
Table 2. Relative poverty rates among population groups ${ }^{1}$

\begin{tabular}{|c|c|c|c|c|c|c|}
\hline & 2009 & 2010 & 2011 & 2012 & 2013 & 2014 \\
\hline All & 12.4 & 13.2 & 13.1 & 14.7 & 14.8 & 13.8 \\
\hline \multicolumn{7}{|l|}{ Gender } \\
\hline Men & 11.9 & 13.0 & 13.4 & 15.4 & 15.4 & 14.5 \\
\hline Women & 12.9 & 13.3 & 12.9 & 14.1 & 14.2 & 13.1 \\
\hline \multicolumn{7}{|l|}{ Age } \\
\hline $0-17$ & 15.4 & 16.5 & 16.6 & 18.5 & 16.9 & 15.5 \\
\hline $18-29$ & 13.0 & 14.0 & 15.2 & 18.0 & 18.8 & 17.7 \\
\hline $30-44$ & 12.9 & 14.4 & 14.4 & 16.7 & 16.1 & 14.8 \\
\hline $45-64$ & 10.8 & 12.2 & 12.6 & 15.1 & 15.8 & 16.1 \\
\hline $65+$ & 10.6 & 9.3 & 7.4 & 5.8 & 6.7 & 4.9 \\
\hline \multicolumn{7}{|l|}{ Area } \\
\hline Athens & 10.0 & 11.5 & 12.2 & 15.7 & 15.1 & 14.4 \\
\hline Rural/semi-rural areas & 14.2 & 14.5 & 13.8 & 14.4 & 14.9 & 13.9 \\
\hline \multicolumn{7}{|l|}{ Tenure } \\
\hline Rent or mortgage & 13.3 & 15.6 & 15.9 & 19.3 & 18.2 & 17.2 \\
\hline No housing costs & 11.8 & 11.8 & 11.6 & 12.2 & 12.8 & 11.9 \\
\hline \multicolumn{7}{|l|}{ Educational attainment } \\
\hline Not completed primary education & 14.8 & 15.1 & 14.6 & 15.9 & 16.0 & 14.9 \\
\hline Upper secondary & 11.7 & 13.4 & 13.8 & 16.3 & 16.5 & 15.4 \\
\hline Tertiary & 3.4 & 4.2 & 5.2 & 6.2 & 7.0 & 7.1 \\
\hline \multicolumn{7}{|l|}{ Labour market status } \\
\hline Unemployed & 22.9 & 29.7 & 31.5 & 34.9 & 32.8 & 32.0 \\
\hline Employee (private excl. banking) & 5.4 & 5.7 & 5.3 & 7.0 & 5.2 & 4.7 \\
\hline Employee (public incl. banking) & 0.7 & 0.7 & 0.6 & 0.6 & 1.5 & 1.0 \\
\hline Liberal profession & 4.6 & 4.8 & 4.9 & 6.6 & 6.9 & 6.9 \\
\hline Own account worker & 13.0 & 15.5 & 14.5 & 15.0 & 20.3 & 18.8 \\
\hline Farmer & 20.8 & 18.8 & 17.7 & 17.7 & 17.3 & 16.7 \\
\hline Student & 16.1 & 16.8 & 17.1 & 18.2 & 17.1 & 15.4 \\
\hline $\begin{array}{l}\text { Poverty threshold } \\
\text { (€ per month, single person) }\end{array}$ & 577 & 529 & 476 & 429 & 388 & 387 \\
\hline
\end{tabular}

1. The relative poverty threshold is set at $50 \%$ of the median equivalised household disposable income in each year. Individuals are ranked according to their household disposable income, equalised by the OECD equivalence scale (i.e. square root of household size). Household disposable income is defined as total income, from all sources, of all household members, net of taxes and social insurance contributions.

Source: EUROMOD estimates.

In 2014, relative poverty rates declined ${ }^{7}$ for all population groups with almost no exception, although they remained extremely high in the case of unemployed workers (32\%).The pattern is broadly similar when looking at the "anchored" poverty (Table 3).

7. The decline in poverty rates in 2014 can be almost entirely attributed to the social dividend, without which poverty in 2014 would have been at $15.0 \%$ and $29.2 \%$ (by reference to a relative and a fixed threshold respectively). 
Table 3. "Anchored" poverty rates among population groups ${ }^{1}$

\begin{tabular}{|c|c|c|c|c|c|c|}
\hline & 2009 & 2010 & 2011 & 2012 & 2013 & 2014 \\
\hline All & 8.6 & 13.2 & 18.5 & 24.5 & 29.3 & 27.4 \\
\hline \multicolumn{7}{|l|}{ Gender } \\
\hline Men & 8.1 & 13.0 & 18.3 & 24.7 & 29.6 & 27.7 \\
\hline Women & 9.2 & 13.4 & 18.7 & 24.4 & 29.0 & 27.1 \\
\hline \multicolumn{7}{|l|}{ Age } \\
\hline $0-17$ & 11.7 & 16.5 & 21.1 & 28.4 & 31.6 & 29.8 \\
\hline $18-29$ & 8.8 & 14.0 & 21.3 & 30.2 & 35.0 & 34.3 \\
\hline $30-44$ & 9.5 & 14.4 & 19.2 & 24.8 & 29.5 & 27.8 \\
\hline $45-64$ & 7.6 & 12.2 & 17.6 & 24.4 & 28.4 & 28.1 \\
\hline $65+$ & 6.0 & 9.4 & 14.3 & 16.4 & 23.6 & 18.3 \\
\hline \multicolumn{7}{|l|}{ Area } \\
\hline Athens & 5.9 & 11.5 & 17.7 & 25.9 & 27.7 & 28.0 \\
\hline Rural/semi-rural areas & 10.4 & 14.5 & 19.4 & 24.2 & 30.8 & 27.7 \\
\hline \multicolumn{7}{|l|}{ Tenure } \\
\hline Rent or mortgage & 9.7 & 15.6 & 21.2 & 29.2 & 33.8 & 32.7 \\
\hline No housing costs & 8.0 & 11.9 & 17.0 & 21.9 & 26.7 & 24.4 \\
\hline \multicolumn{7}{|l|}{ Educational attainment } \\
\hline Not completed primary education & 10.9 & 15.2 & 20.8 & 26.6 & 33.1 & 30.4 \\
\hline Upper secondary & 8.1 & 13.4 & 19.2 & 26.2 & 30.1 & 29.6 \\
\hline Tertiary & 2.4 & 4.2 & 7.0 & 11.1 & 13.3 & 13.4 \\
\hline \multicolumn{7}{|l|}{ Labour market status } \\
\hline Unemployed & 16.3 & 29.8 & 41.9 & 48.2 & 52.7 & 51.2 \\
\hline Employee (private excl. banking) & 3.2 & 5.7 & 8.9 & 14.8 & 17.3 & 16.8 \\
\hline Employee (public incl. banking) & 0.2 & 0.7 & 1.2 & 2.2 & 2.9 & 2.8 \\
\hline Liberal profession & 1.6 & 4.8 & 5.1 & 6.8 & 9.4 & 9.4 \\
\hline Own account worker & 10.6 & 15.5 & 16.8 & 21.3 & 29.2 & 27.8 \\
\hline Farmer & 14.2 & 19.0 & 23.0 & 25.3 & 32.0 & 28.0 \\
\hline Student & 11.5 & 16.8 & 22.3 & 30.6 & 33.5 & 32.1 \\
\hline $\begin{array}{l}\text { Poverty threshold } \\
\text { (€ per month, single person) }\end{array}$ & 508 & 531 & 549 & 557 & 552 & 545 \\
\hline
\end{tabular}

1. The fixed poverty threshold is set at $50 \%$ of median equivalised household disposable income in the year 2005 , adjusted for inflation. Individuals are ranked according to their household disposable income, equalised by the OECD equivalence scale (i.e. square root of household size). Household disposable income is defined as total income, from all sources, of all household members, net of taxes and social insurance contributions. For the adjustment of the poverty line inflation, the OECD price index was used.

Source: EUROMOD estimates.

\section{How has the burden of the adjustment been distributed?}

\section{Distinguishing the effects of consolidation policies from recession}

As discussed earlier, micro-simulation techniques allow to distinguish, to the extent possible (given their inter-relation), the impact of worsening of economic conditions and policy changes (in the current context, fiscal consolidation policies) on the distribution of incomes over the period 2009-2014 (Box 2). These simulations quantify the relative impact of consolidation measures on income distribution, ceteris paribus (the residuals being attributed to economic conditions). Although the estimates capture solely the first-order effects on poverty and inequality, leaving out both the potential behavioural responses and interactions between fiscal consolidation and the recession, they provide useful insights on the distributional impact of the fiscal consolidation measures. 


\section{Box 2. Estimating the distributional effects of fiscal consolidation versus recession}

The following micro-simulations were undertaken to distinguish the ceteris paribus effects of fiscal consolidation (narrowly defined as a set of consolidation policies) on inequality and poverty from those of the wider recession (in the form of rising unemployment and falling earnings in the private sector). The exercise is equivalent to assuming zero fiscal multiplier, or that government policies in a specific year raised taxes and cut public sector pay, pensions and other social benefits, but left nominal pre-tax incomes and jobs in the private sector at the previous year's level). More specifically:

- $\quad$ For the production of the "fiscal consolidation alone" results, the micro-simulation model was run for year t on the basis of:

$>\quad$ year t-1 dataset as input dataset (i.e. no labour market adjustments);

$>\quad$ year t-1 uprating factors for (i) employment income variables of private sector employees outside banking and banking employees, and (ii) self-employment income variables of farmers, own account workers and liberal professions;

$>$ year $t$ uprating factors for all other variables (i.e. employment income of public sector workers, non-simulated social benefits etc.);

$>$ year $t$ tax and benefit policies.

- For the production of the "fiscal consolidation and recession" results, the model was run again for year $t$ on the basis of:

$>\quad$ year t dataset as input dataset (i.e. with labour market adjustments);

> year t uprating factors for (i) employment income variables of private sector employees outside banking and banking employees, and (ii) self-employment income variables of farmers, own account workers and liberal professions;

as well as:

$>$ year t uprating factors for all other variables (i.e. employment income of public sector workers, non-simulated social benefits etc.);

$>\quad$ year $t$ tax and benefit policies.

The difference (labour market adjustments plus change in incomes of employment and self-employment in the private sector) is an approximation of the effect of recession, over and above the effect of fiscal consolidation policies.

Note, however, that the approximation is imperfect. Firstly, changes in non-monetary incomes (such as those resulting from cuts in the funding of public services) are not taken into account. On the other hand, some developments in the wider economy are in reality directly attributable to government policy (e.g. changes in minimum wage legislation). Thirdly, the neat separation of 'the recession' from 'the fiscal consolidation' assumes zero effects of fiscal consolidation on output, which is clearly untrue. In fact, recent research has shown that the nature of the interaction between fiscal consolidation and growth depends on the size and content of fiscal consolidation, and on the characteristics of the economy in question, although the direction and magnitude of the relevant effects remains a matter of debate. For a fuller discussion, see Matsaganis and Leventi (2014).

On the basis of micro-simulations, early fiscal consolidation policies per se appear to have had a small impact on inequality and relative poverty, partly mitigating the effects of the recession (Table 4). As consolidation intensified in 2012, the measures appeared to have (slightly but significantly) contributed to rising poverty and inequality. From 2013, fiscal consolidation policies ${ }^{8}$ seem to have had a more equalizing effect, especially at the bottom of the distribution and in terms of its distance from the top. As for the proportion of population whose income fell below a poverty line anchored in 2005 in real terms, it increased with each round of fiscal consolidation, and was given a further boost by the rise in unemployment, until 2014 when it finally stabilised.

8. Note that consolidation policies as intended here include certain compensatory measures, such as for example single child benefit (introduced in 2013) and social dividend (introduced in 2014). 
ECO/WKP(2016)36

Table 4. Disaggregating the first-order effects of fiscal consolidation and the wider recession

\begin{tabular}{|c|c|c|c|c|c|c|}
\hline & 2009 & 2010 & 2011 & 2012 & 2013 & 2014 \\
\hline \multicolumn{7}{|l|}{ Income inequality } \\
\hline \multicolumn{7}{|l|}{ Gini index } \\
\hline Fiscal consolidation alone $^{1}$ & \multirow[t]{2}{*}{0.326} & 0.321 & 0.33 & 0.336 & 0.347 & 0.343 \\
\hline Fiscal consolidation + recession & & 0.332 & 0.336 & 0.346 & 0.349 & 0.342 \\
\hline \multicolumn{7}{|l|}{ S80/S20 } \\
\hline Fiscal consolidation alone & \multirow[t]{2}{*}{5.4} & 5.3 & 5.6 & 6 & 6.5 & 6.5 \\
\hline Fiscal consolidation + recession & & 5.7 & 5.9 & 6.7 & 6.8 & 6.5 \\
\hline \multicolumn{7}{|l|}{ S90/S10 $-4-2-3$} \\
\hline Fiscal consolidation alone & \multirow[t]{2}{*}{8.9} & 8.7 & 9.9 & 11.1 & 13.5 & 14.5 \\
\hline Fiscal consolidation + recession & & 9.8 & 11.1 & 14.1 & 15.3 & 14.3 \\
\hline \multicolumn{7}{|l|}{$\begin{array}{l}\text { Poverty } \\
\end{array}$} \\
\hline \multicolumn{7}{|l|}{ Relative $^{2}$} \\
\hline Fiscal consolidation alone & \multirow[t]{2}{*}{12.4} & 12.3 & 13 & 13.4 & 13.4 & 13.8 \\
\hline Fiscal consolidation + recession & & 13.2 & 13.1 & 14.7 & 14.8 & 13.8 \\
\hline \multicolumn{7}{|l|}{ 'Anchored'3 } \\
\hline Fiscal consolidation alone & \multirow[t]{2}{*}{8.6} & 10.5 & 16.2 & 20.1 & 25.9 & 27 \\
\hline Fiscal consolidation + recession & & 13.2 & 18.5 & 24.5 & 29.3 & 27.4 \\
\hline
\end{tabular}

1. The impact of fiscal consolidation policies in year $t$ is assessed relative to the state of the economy in $t-1$, which is equivalent to assuming that government policies altered public sector pay, public pensions, taxes and benefits, but left nominal pre-tax market incomes and employment levels as in the year before.

2. The poverty line is $50 \%$ of median equivalised disposable income in each year.

3. The poverty line is fixed at $50 \%$ of median equivalised household disposable income in 2005.

Source: Based on micro-simulation analysis (EUROMOD).

\section{Disaggregating the impact of consolidation policies}

The redistributive impact of each fiscal consolidation policy (for a detailed description see Annex A1) on inequality can be formally assessed with the change in the value of the Gini index. Table 5 shows the difference between the counterfactual value of the Gini coefficient in the absence of all consolidation measures being assessed, and its actual value after the implementation of each of these measures in turn (Leventi and Matsaganis, 2013).

Overall, the results from the micro-simulation suggest that measures which either placed a higher burden on high incomes, or mostly affected households at the top of income distribution (such as cuts in public sector pay and pensioners' solidarity contributions), cushioned the impact on inequality. On the contrary, policies adversely affecting low-income households (such as the 2012 cut in unemployment benefits), or easing the burden on higher incomes (such as the 2013 income tax changes) had an opposite, inequality-increasing effect.

More specifically, micro-simulation estimates for the period 2010 to 2014 indicate that changes in child benefits, pensioners' solidarity contribution (in effect, a rather steep levy on higher pensions), and cuts in public sector pay were progressive (Table 5). Furthermore, changes in personal income taxes (in 2010-2011 and 2014), cuts in pension benefits (in 2010), and reductions in property taxation (in 2013) also seemed to have a progressive effect, though weaker and/or intermittent. 
On the other hand, the 2012 cuts in unemployment benefits (Table 5), and the 2014 changes in eligibility for EKAS were regressive, as were the 2010 VAT hikes ${ }^{9}$. Increasing social contributions for self-employed workers and members of the liberal professions also seemed to make the income distribution more unequal overall. Moreover, changes in income taxation (in 2013), cuts in pension benefits (in 2013), and changes in property taxation (in 2011 and 2014) had a regressive effect.

Table 5. Identifying the effect of individual policies on inequality

Changes in the Gini index (in percentage points) ${ }^{1}$

\begin{tabular}{|c|c|c|c|c|c|}
\hline & 2010 & 2011 & 2012 & 2013 & 2014 \\
\hline income taxes & 0.00551 & 0.00388 & no change & -0.00520 & 0.00019 \\
\hline public sector pay & 0.00165 & 0.00016 & 0.00079 & 0.00122 & no change \\
\hline pension benefits & 0.00075 & no change & no change & -0.00193 & no change \\
\hline pensioners' solidarity contributions ${ }^{2}$ & 0.00041 & 0.00048 & 0.00180 & 0.00073 & no change \\
\hline social insurance contributions & no change & 0.00008 & -0.00005 & -0.00010 & -0.00004 \\
\hline self-employed \& liberal prof. contribution & -0.00030 & -0.00012 & -0.00030 & no change & no change \\
\hline property taxes $^{3}$ & no change & -0.00252 & no change & 0.00045 & -0.00074 \\
\hline child benefits $^{4}$ & no change & no change & no change & 0.00661 & no change \\
\hline EKAS $^{5}$ & no change & no change & no change & no change & -0.00080 \\
\hline unemployment insurance benefit & no change & no change & -0.00107 & no change & no change \\
\hline
\end{tabular}

1. The table shows the percentage point difference between the counterfactual value of the Gini coefficient in the absence of all fiscal consolidation measures presented in the table for a specific year (i.e. on the basis of previous year's policies) relative to its value after the implementation of the fiscal consolidation measure in question. Positive (negative) values indicate progressive (regressive) impact. For a detailed description of policies, see Annex A1.

2. Solidarity contributions levied on main and supplementary pensions.

3. Emergency property tax in introduced in 2011; reduced by $15 \%$ in 2013 ; replaced by "single tax on immovable assets" in 2014, when additional tax on rental income abolished. Information on second homes not available in the data.

4. $\quad 3^{\text {rd }}$ child benefit, birth grant and lifetime pension for mothers of many children abolished, large family benefit became meanstested, single child benefit introduced in 2013.

5. EKAS: Income-tested supplement aimed at recipients of old age and survivor pension. Age threshold raised from 60 to 65 in 2014.

Source: Based on micro-simulation analysis (EUROMOD).

Detailed analysis of the impact of each consolidation measure by household income decile group tends to support the above findings (Figures 2, 3 and 4). A strong progressive impact can be seen for, example, in the case of direct tax changes in 2010, with the greatest losses incurred by the top decile, while public pension cuts affected mostly the middle of the distribution. On the other hand, some policies (such as the introduction of emergency property tax in 2011, the cut in unemployment benefits in 2012, the changes in personal income tax in 2013 and the changes in property taxation in 2014) had a larger negative impact on the lowest decile than on those further up the income scale.

9. The distributional impact of changes in indirect taxes, such as VAT, cannot be analysed in terms of income since these taxes affect consumption. For a separate analysis, confirming that the 2010 VAT hikes were highly regressive, see Matsaganis and Leventi (2013). 
Figure 2. Change in household disposable income due to consolidation, 2010 and 2011

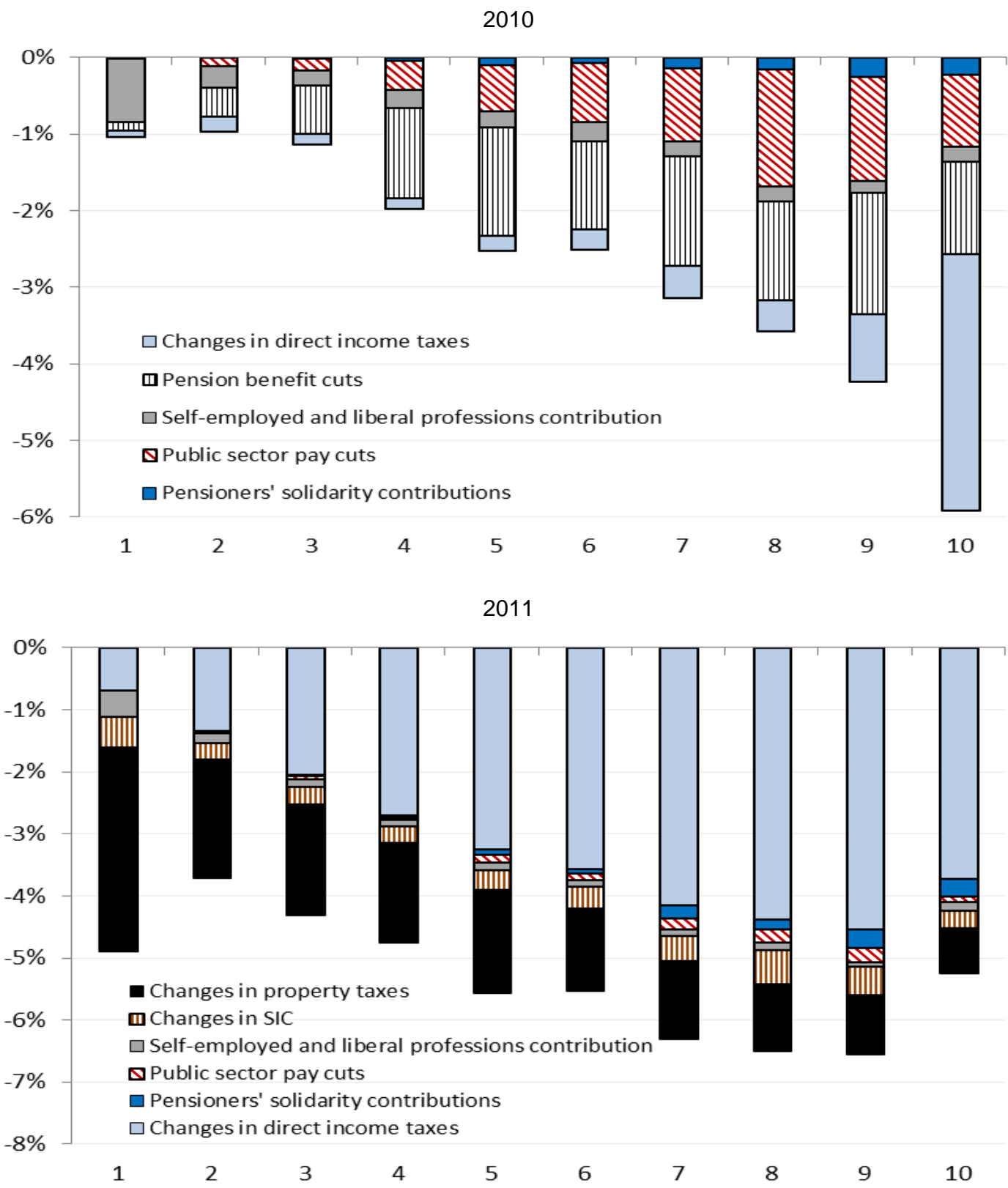

Note: Income deciles were equivalised according to the OECD equivalence scale (i.e. square root of household size). Household disposable income is defined as total income, from all sources, of all household members, net of taxes and social insurance contributions. For an analytical description of the policy measures see Annex A1.

Source: EUROMOD estimates. 
Figure 3. Change in household disposable income due to consolidation, 2012 and 2013
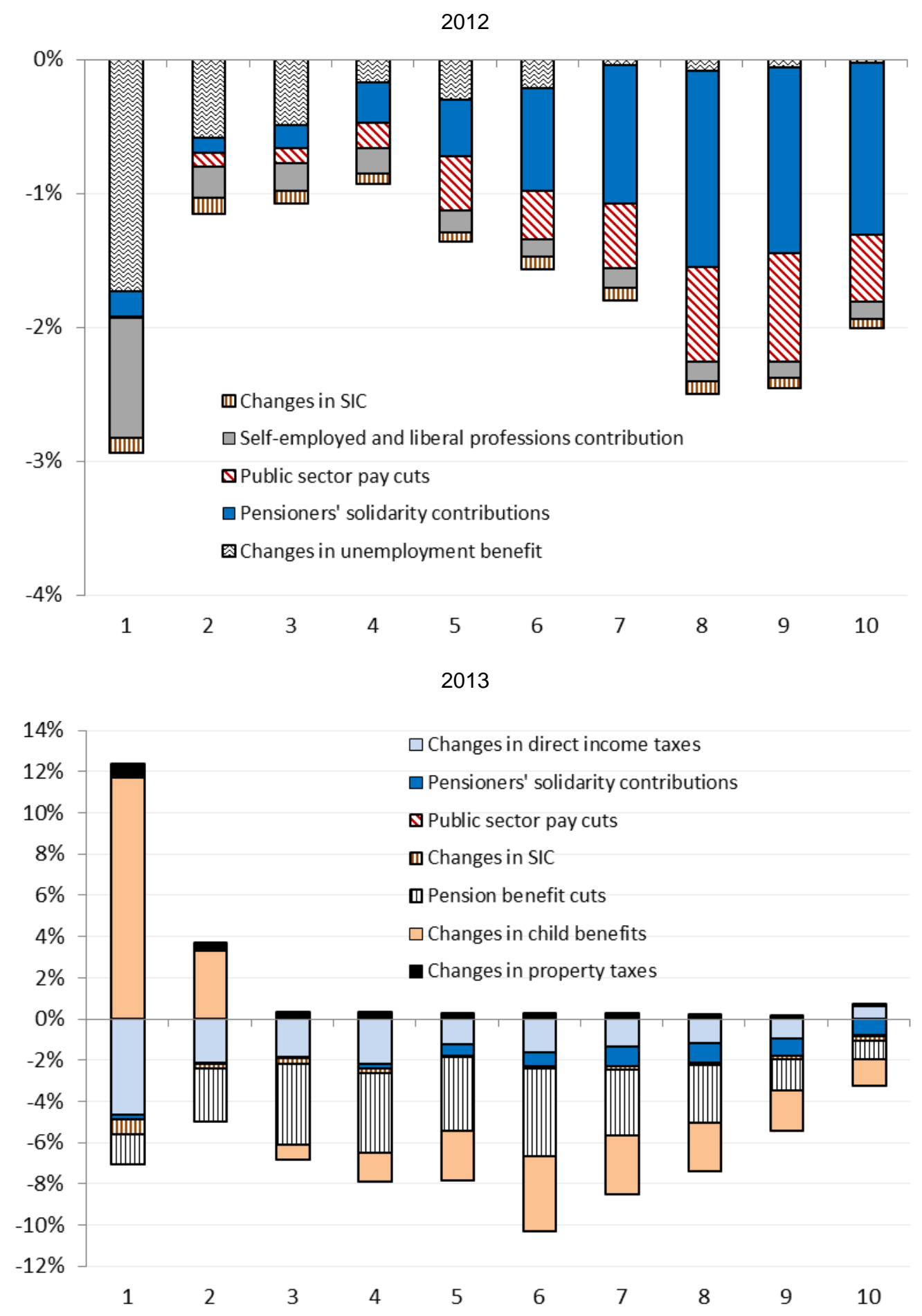

Note: Income deciles were equivalised according to the OECD equivalence scale (i.e. square root of household size). Household disposable income is defined as total income, from all sources, of all household members, net of taxes and social insurance contributions. For an analytical description of the policy measures see Annex A1.

Source: EUROMOD estimates. 
Figure 4. Change in household disposable income due to consolidation, 2014

2014

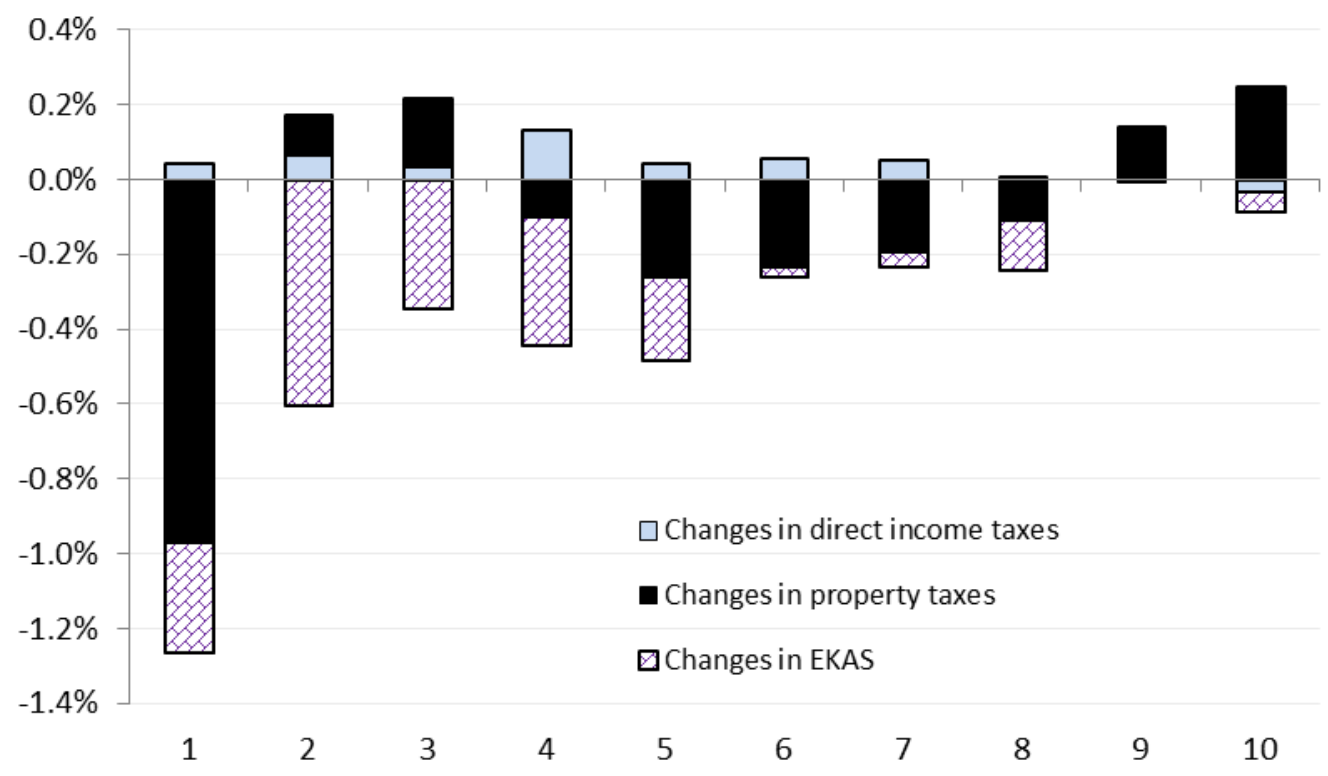

Note: Income deciles were equivalised according to the OECD equivalence scale (i.e. square root of household size) Household disposable income is defined as total income, from all sources, of all household members, net of taxes and social insurance contributions. For an analytical description of the policy measures see Annex A1.

Source: EUROMOD estimates. 


\section{BIBLIOGRAPHY}

Atkinson, A. (1970) "On the Measurement of Inequality", Journal of Economic Theory, vol. 2, pp. 244263.

Bellu, G., and Liberati, P. (2006) "Inequality Analysis - The Gini Index", Food and Agriculture Organization, United Nations.

Immervoll H., et al. (2006) "The sensitivity of poverty rates to macro-level changes in the European Union", Cambridge Journal of Economics, vol. 30, pp. 181-199.

Jara, X.H., and Leventi, C. (2014) "Baseline results from the EU27 EUROMOD (2009-2013)", EUROMOD Working Paper EM18/14, Colchester: ISER, University of Essex.

Koutsogeorgopoulou, V. et al. (2014), "Fairly Sharing the Social Impact of the Crisis in Greece", OECD Economics Department Working Papers, No. 1106, OECD Publishing. http://dx.doi.org/10.1787/5jzb6vwk338x-en

Leventi C., Matsaganis, M. and Flevotomou, M. (2013) "Distributional implications of tax evasion and the crisis in Greece. EUROMOD Working Paper EM17/13”, Colchester: ISER, University of Essex.

Leventi, C., and Matsaganis, M. (2013) "Distributional Implications of the Crisis in Greece in 2009-2012", EUROMOD Working Paper No. EM 14/13, August.

Matsaganis, M., and Leventi, C. (2013) “The distributional impact of the Greek crisis in 2010”, Fiscal Studies, vol. 34, no. 1, pp. 83-108.

Matsaganis, M., and Leventi, C. (2014) "The distributional impact of fiscal consolidation and the recession in Southern Europe", South European Society and Politics, vol. 19, no. 3, pp. 393-412.

OECD (2013) Economic Policy Reforms: 2013: Going for Growth, OECD Publishing, Paris.

OECD. (2016), OECD Economic Surveys: Greece 2016, OECD Publishing, Paris. http://dx.doi.org/10.1787/eco surveys-grc-2016-en

Paulus, A. et al. (2010) "The Distributional Impact of In-Kind Public Benefits in European Countries", Journal of Policy Analysis and Management, vol. 29, pp. 243-266.

Rastrigina O., Leventi C., and Sutherland, H. (2015) "Nowcasting: estimating developments in the risk of poverty and income distribution in 2013 and 2014", Research Note 1/2014, Social Situation Monitor: European Commission.

Sutherland, H., and Figari, F. (2013) "EUROMOD: The European Union Tax-Benefit Microsimulation Model”, EUROMOD Working Paper No. EM 8/13, March.

Sutherland, S. (2001) "EUROMOD: An Integrated European Benefit-Tax Model - Final Report: Executive Summary", A Project Financed by the Targeted Socio-Economic Research Programme of the European Commission. 
ANNEX A1.

\section{FISCAL CONSOLIDATION POLICIES IN GREECE (2010-2014)}

The 2010-2014 fiscal consolidation measures that affected household incomes comprised expenditure cuts and tax hikes and changes in labour laws. More specifically:

\section{Public sector pay}

- The $13^{\text {th }}$ and $14^{\text {th }}$ salaries paid to civil servants and public enterprise workers until the onset of the crisis were abolished in 2010. In their place, flat-rate vacation allowances totalling EUR 1000 a year were introduced for public sector workers earning less than EUR 3000 per month. These allowances were abolished in 2013.

- Special allowances paid to civil servants were reduced by $20 \%$ in 2010. Public enterprise workers, whose special allowances other than family allowances are part of base pay, had the latter cut by $10 \%$.

- Public sector salaries were frozen at their 2009 level and capped at EUR 5981 per month (to EUR 4750 since 2013).

\section{Pension benefits}

The $13^{\text {th }}$ and $14^{\text {th }}$ pensions were abolished (save few exemptions) in 2010 and replaced by flat-rate vacation allowances totalling EUR 800 a year (payable only to pensioners aged over 60 receiving a pension below EUR 2500 per month). In January 2013 flat-rate vacation allowances were also abolished.

\section{Social benefits}

The payment of housing benefit (OEK rent benefit for private sector employees, the main housing benefit in Greece) was suspended for 2010 and completely abolished in 2012.

The $13^{\text {th }}$ and $14^{\text {th }}$ payment of EKAS (an income-tested supplement aimed at recipients of old age and survivor pension) was also abolished in 2010. Moreover, as a result intensified efforts against benefit fraud, some ineligible recipients of EKAS and the social pension (a non-contributory, income-tested pension, reserved for people over 65 years of age who lack independent means of support) had inevitably their benefit suspended. The age limit was raised to 65 (from 60) in 2014.

In March 2012 the unemployment insurance benefit was reduced by 22\% (from EUR 454 to EUR 360 per month).

Social pension: the $13^{\text {th }}$ and $14^{\text {th }}$ month payments were abolished in 2013; the age condition was raised to 67 (from 65) in 2014.

Social dividend: a lump-sum benefit, ranging from EUR 500 to EUR 1000 (depending on family size), paid to households passing a test of incomes and assets in 2014. The benefit receipt was cash-limited to approximately $€ 450$ million. 
Family benefits: $3^{\text {rd }}$ child benefit, lump sum EUR 2000 birth grant and lifetime pension for mothers of many children were abolished; large family benefit became means-tested; a new (means-tested) child benefit was introduced (all in 2013).

Unemployment assistance for older workers: the income threshold was raised from EUR 5000 to EUR 12000 per year in 2013. In 2014 it fell to EUR 10000 and the age limits were increased from 45-65 to $20-66$.

\section{Direct taxation}

- Personal income tax (PIT). In 2010-2014 personal income tax was restructured three times (April 2010, October 2011 and December 2012). The most important changes of the first two reforms are shown in Table A1.1. The third PIT reform affected incomes earned in 2013 and beyond. A new tax schedule with three tax brackets was introduced for income deriving from employment and pensions. Self-employment income is taxed by a separate tax schedule with two tax brackets. A different tax schedule for rental income (two tax bands) was introduced. The zero tax bracket was abolished and an employment tax credit was introduced. The tax credit is equal to EUR 2100 if employment income is up to EUR 21000 per year. It is capped to the amount of people's actual tax liability (i.e. no negative tax applies). The tax credit is decreased by EUR 100 for each additional EUR 1000 of employment income over EUR 21000 . Farmers were taxed according to the tax schedule used for income deriving from employment and pensions. Tax credits for rent, education expenses, mortgage interest, private insurance contributions, and installation of eco-friendly energy systems were abolished. Disability tax allowance was turned into a tax credit. In 2014 a flat tax of $13 \%$ was introduced for farmers, the taxable income threshold above which certain benefits are taxed fell from EUR 30000 to EUR 10000 per year and the tax rate of the first band of rental income was increased by one percentage point.

- Emergency tax on large incomes. In 2010 personal incomes over EUR 100000 earned in 2009 were made subject to a one-off emergency tax at $1 \%$.

- Interest income tax. Its rate was increased from 10\% to $15 \%$ in 2013.

- Solidarity contribution. An emergency tax introduced in 2010, paid by individuals with taxable incomes exceeding EUR 12000 per year, with contribution rates rising from 1\% (for incomes between EUR 12000 and EUR 20000 per year) to 4\% (for incomes over EUR 100000 per year). The tax rates apply to the entire amount of income (not just the part exceeding the threshold). 
ECO/WKP(2016)36

Table A1.1 Changes in personal income tax

\begin{tabular}{|c|c|c|c|}
\hline & 2009 & 2010 & $2011-2012$ \\
\hline Tax bands & 5 & 9 & 8 \\
\hline Max tax rate & $40 \%$ (for annual incomes over $€ 75000$ ) & $45 \%$ (for annual incomes over $€ 100000$ ) & same as in 2010 \\
\hline Zero tax bracket & $\begin{array}{l}\text { - } € 12,000 \text { for employees and } \\
\text { pensioners } \\
\text { - } € 10,500 \text { for all others }\end{array}$ & - $€ 12,000$ for all & $\begin{array}{l}\text { - } € 9,000 \text { for persons aged } \\
\text { below } 30 \text { or above } 65 \\
\text { - } € 5,000 \text { for all others }\end{array}$ \\
\hline $\begin{array}{l}\text { Increase in zero income } \\
\text { tax bracket due to } \\
\text { children }\end{array}$ & $\begin{array}{l}\text { - } 1^{\text {st }} \text { child: } € 1,000 \text { increase } \\
\text { - } 2^{\text {nd }} \text { child: } € 2,000 \text { increase } \\
\text { - } 3^{\text {rd }} \text { child: } € 10,000 \text { increase }\end{array}$ & $\begin{array}{l}\text { - } 1^{\text {st }} \text { child: } € 1,500 \text { increase } \\
\text { - } 2^{\text {nd }} \text { child: } € 3,000 \text { increase } \\
\text { - } 3^{\text {rd }} \text { child: } € 11,500 \text { increase }\end{array}$ & $\begin{array}{l}\text { - } 1^{\text {st }} \text { child: } € 2,000 \text { increase } \\
\text { - } 2^{\text {nd }} \text { child: } € 4,000 \text { increase } \\
\text { - } 3^{\text {rd }} \text { child: } € 7,000 \text { increase }\end{array}$ \\
\hline Tax allowances / credits & $\begin{array}{l}\text { spending on private insurance / } \\
\text { installation of eco-friendly energy } \\
\text { systems eligible for tax allowance }\end{array}$ & $\begin{array}{l}\text { spending on private insurance / } \\
\text { installation of eco-friendly energy } \\
\text { systems eligible for tax credit }\end{array}$ & $\begin{array}{l}\text { tax credits: } 50 \% \text { reduced } \\
\text { tax allowances: abolished }\end{array}$ \\
\hline
\end{tabular}

1. In 2009 a further EUR 1000 increase in the lowest income bracket is applicable for each subsequent child after the third. In 2010 (2011-12) a further EUR 2000 (EUR 3 000) increase in the lowest income bracket is applicable for each subsequent child after the third.

2. Since 2010 the tax base was extended to include unemployment benefits, large family benefits and non-contributory disability benefits, when taxable income exceeded EUR 30000 a year.

\section{Self-employed and liberal professions contribution}

- A special levy on self-employed and liberal professions was introduced in 2010, with the tax set to EUR 300 per year. In 2011 (2012-2014) it amounted to EUR 500 (EUR 650) for those selfemployed and liberal professionals working more than five years in areas with population exceeding 200000 inhabitants and EUR 400 (EUR 650) for those working more than five years in areas with population between 500 and 200000 inhabitants. No tax was levied for selfemployed and liberal professionals working in areas with less than 500 inhabitants.

\section{Pensioners' solidarity contributions (main and pensions)}

- The first special levy on pension incomes (labelled 'Pensioners' solidarity contribution') was introduced in August 2010. Since then, main old-age pensions exceeding EUR 1400 per month are subject to taxation with the rates rising from 3\% for pensions between EUR 1400 and EUR 1700 per month to 10\% (14\% in 2011-2014) for pensions over EUR 3500 per month.

- An additional levy on main old-age pensions was introduced in August 2011. The contribution applies to pensioners below 60 (except from mothers of underage children) with main pensions exceeding EUR 1700 per month. The contributions' rates rise from $6 \%$ for pensions between EUR 1700 and EUR 2300 per month to $10 \%$ for pensions over EUR 2900 per month. The tax rates apply to all pension income minus the 'pensioners' solidarity contribution'.

- Since November 2011 all pensioners below 55 with main old-age pensions exceeding EUR 1000 are subject to $40 \%$ taxation. Persons aged above 55 with main old-age pensions exceeding EUR 1200 are subject to $20 \%$ taxation. The tax rates apply to the pension amount exceeding the above thresholds after all other solidarity contributions concerning main pensions have been deducted.

- Since January 2012 all main old-age pensions exceeding EUR 1300 are subject to an extra 12\% taxation. The tax rate applies to the pension amount exceeding EUR 1300 after the deduction of all the above mentioned solidarity contributions. Pensions are not allowed to fall below EUR 1300. 
- $\quad$ Since August 2011 supplementary pensions exceeding EUR 300 per month are also subject to taxation, with tax rates rising from 3\% for pensions between EUR 300 and EUR 350 per month to $10 \%$ for pensions exceeding EUR 650 per month. In January 2012 an additional tax for supplementary pensions was introduced with rates increasing from $10 \%$ for pensions up to EUR 250 to $20 \%$ for pensions over EUR 300 per month.

- Since January 2013 if the sum of main and supplementary pensions exceeds EUR 1000 they are subject to an additional levy varying from $5 \%$ to $20 \%$.

\section{Property taxation}

- In 2011-2013 all owners of commercial or residential property in Greece were subject to an emergency property tax. The tax, varying from EUR 3 to EUR 16 per square meter, was a function of the cadastral value of the building and its size. A specific factor varying from 1 to 1.25 according to the age of the building was also applicable (property tax $=$ tax rate $\times$ square meters $\times$ age factor). ${ }^{10}$ A reduced rate of $€ 0.50$ per square meter applied to vulnerable population groups (that is, families with more than three children and yearly taxable income below EUR 30000 per year or persons with severe disability). Long term unemployed or recipients of unemployment benefit for more than 6 months, with family income not exceeding EUR 12000 per year (plus EUR 4000 for every dependent child) were exempted from the tax. In 2013 the tax was reduced by 15\%. In 2014 the additional tax on rental incomes was abolished and emergency property tax was replaced by the 'Unified Property Tax'. In addition to commercial and residential properties, land is also subject to the latter.

\section{Social insurance contributions}

- In August 2011 private sector employees' and employers' social insurance contributions for unemployment protection were increased by $0.5 \%$. The respective civil servants' and selfemployed workers' contributions were increased by $2 \%$ and EUR 10 per month respectively. Contributions for liberal professionals working as self-employed (i.e. doctors, lawyers, engineers) increased in 2012; the upper earnings threshold for the calculation of contributions of employees first insured before 1993 increased in 2013.

- Employers' contributions for sickness insurance and other benefits were reduced in June 2014 $(-0.55 \%$ and $-1.25 \%$ respectively). Employers' and employees' contributions for family benefits (1\% respectively) were abolished.

- Farmers' contributions for sickness insurance were increased in January 2013. Contributions for supplementary pension for banking employees, civil servants and public enterprise workers were unified for people first insured before and after 1993 in December 2013. The new rate is equal to $3 \%$.

10. Due to the lack of information on the age of buildings, in EUROMOD the age factor was set to 1 for all of the tax payers. The tax rates per square meter used, taken from Leventi and Matsaganis (2013), were the average rates for urban and rural/ semi-rural areas according to a large tax data sample provided by the Greek authorities (i.e. EUR 5.30 per square meter for those residing in urban areas and EUR 3.70 per square meter for those residing in rural/ semi-rural areas). The use of average tax rates introduces a first source of bias. Moreover, the fact that the simulation of the emergency tax is based on EU-SILC data on home ownership of main residence, which does not provide information as to whether the household also owns a second home, introduces a second source of bias. 


\section{Indirect taxation}

- The standard rate of VAT was increased from $19 \%$ to $23 \%$ in two steps between March and May 2010. Base and reduced rates were increased from $4.5 \%$ to $5.5 \%$ and from $9 \%$ to $11 \%$ respectively. Excise duties on alcohol, tobacco, luxury items, and especially heating oil, also went up.

\section{Labour market regulation}

- In 2010 entry wages for workers aged below 25 were allowed to be set $20 \%$ below the statutory minimum for a maximum duration of one year. Moreover, in February 2012 minimum wage was cut by $22 \%$ for workers aged above 25 and $32 \%$ for workers below 25 . These changes were captured indirectly in EUROMOD by using Bank of Greece estimates for earnings growth. 
ANNEX A2.

EUROMOD UPRATING FACTORS AND LABOUR MARKET ADJUSTMENTS

Table A.2.1 EUROMOD uprating factors: incomes

\begin{tabular}{lllllll}
\hline & 2009 & 2010 & 2011 & 2012 & 2013 & 2014 \\
\hline employment earnings & & & & & & \\
\hline dependent employment earnings & 1.000 & 0.954 & 0.938 & 0.876 & 0.819 & 0.807 \\
\hline public sector employees & 1.000 & 0.923 & 0.918 & 0.884 & 0.873 & 0.873 \\
\hline workers in public enterprises & 1.000 & 0.945 & 0.870 & 0.788 & 0.709 & 0.709 \\
\hline private sector employees excl. banking & 1.000 & 0.971 & 0.955 & 0.866 & 0.797 & 0.785 \\
\hline banking employees & 1.000 & 0.982 & 0.983 & 0.909 & 0.818 & 0.767 \\
\hline self-employed earnings & & & & & & 1.000 \\
\hline Farmers & 1.000 & 0.958 & 1.019 & 1.055 & 1.018 & 1.000 \\
\hline own account workers & 1.000 & 0.954 & 0.938 & 0.876 & 0.819 & 0.807 \\
\hline liberal professions & 1.000 & 0.954 & 0.938 & 0.876 & 0.819 & 0.807 \\
investment - property income & & & & & & 1.295 \\
\hline investment income & 1.000 & 1.069 & 1.165 & 1.256 & 1.326 & 0.871 \\
\hline property income - rent & 1.000 & 1.024 & 1.033 & 1.012 & 0.943 \\
\hline other income & & & & & & 0.807 \\
\hline private transfers & 1.000 & 0.954 & 0.938 & 0.876 & 0.819 & 0.807 \\
\hline non-cash income & 1.000 & 0.954 & 0.938 & 0.876 & 0.819 \\
\hline income received by children <16 & 1.000 & 0.954 & 0.938 & 0.876 & 0.819 & 0.807 \\
\hline
\end{tabular}

Source: El.Stat., Bank of Greece.

Table A2.2 EUROMOD uprating factors: assets and expenditure items

\begin{tabular}{lllllll}
\hline & 2009 & 2010 & 2011 & 2012 & 2013 & 2014 \\
\hline Assets & & & & & & \\
\hline loan value & 1.000 & 1.047 & 1.082 & 1.098 & 1.088 & 1.074 \\
\hline financial capital & 1.000 & 1.047 & 1.082 & 1.098 & 1.088 & 1.074 \\
\hline expenditure items & & & & & & \\
\hline rent paid & 1.000 & 1.024 & 1.033 & 1.012 & 0.943 & 0.871 \\
\hline education expenses & 1.000 & 1.047 & 1.082 & 1.098 & 1.088 & 1.074 \\
housing cost & 1.000 & 1.069 & 1.165 & 1.256 & 1.326 & 1.295 \\
\hline interest on mortgage payment & 1.000 & 1.047 & 1.082 & 1.098 & 1.088 & 1.074 \\
\hline other housing costs & 1.000 & 1.069 & 1.165 & 1.256 & 1.326 & 1.295 \\
\hline medical expenses & 1.000 & 1.047 & 1.082 & 1.098 & 1.088 & 1.074 \\
\hline expenses for new heating systems & 1.000 & 1.047 & 1.082 & 1.098 & 1.088 & 1.074 \\
\hline alimony expenditure & 1.000 & 0.982 & 0.982 & 0.975 & 0.953 & 0.950 \\
\hline other maintenance payments & 1.000 & 0.982 & 0.982 & 0.975 & 0.953 & 0.950 \\
\hline expenditure on private pensions & 1.000 & 1.047 & 1.082 & 1.098 & 1.088 & 1.074 \\
\hline nominal GDP deflator & 1.000 & & & & & 1.067 \\
\hline harmonised consumer price index & 1.000 & 1.047 & 1.080 & 1.091 & 1.082 \\
\hline
\end{tabular}

Source: El.Stat., Bank of Greece. 
Table A2.3 EUROMOD uprating factors: non-simulated social benefits

\begin{tabular}{lllllll}
\hline & 2009 & 2010 & 2011 & 2012 & 2013 & 2014 \\
\hline main old age pension & & & & & & 1.000 \\
supplementary old age pensions & 1.000 & 1.000 & 1.000 & 1.000 & 1.000 & 1.000 \\
\hline other minor pensions & 1.000 & 1.000 & 1.000 & 1.000 & 1.000 & 1.00 \\
\hline survivors pensions & 1.000 & 1.000 & 1.000 & 1.000 & 1.000 & 1.000 \\
\hline orphans pensions & 1.000 & 1.000 & 1.000 & 1.000 & 1.000 & 1.000 \\
\hline private pensions & 1.000 & 1.000 & 1.000 & 1.000 & 1.000 & 1.000 \\
minor unemployment benefits & 1.000 & 1.000 & 1.000 & 0.793 & 0.793 & 0.793 \\
\hline minor family benefits & 1.000 & 1.026 & 1.014 & 1.014 & 0.957 & 0.957 \\
contributory maternity benefits & 1.000 & 1.000 & 1.000 & 1.000 & 1.000 & 1.000 \\
\hline health benefits & 1.000 & 0.954 & 0.938 & 0.876 & 0.819 & 0.807 \\
disability pensions & 1.000 & 1.000 & 1.000 & 1.000 & 1.000 & 1.000 \\
\hline disability benefits & 1.000 & 1.082 & 1.168 & 1.168 & 1.168 & 1.168 \\
\hline housing benefits & 1.000 & 1.000 & 1.000 & 1.000 & 1.000 & 1.000 \\
\hline scholarships and grants & 1.000 & 1.000 & 1.000 & 1.000 & 1.000 & 1.000 \\
\hline
\end{tabular}

Source: El.Stat., various benefit agencies.

Table A2.4 Effect of labour market adjustments on employment rates (2009-2014)

\begin{tabular}{rrrrrr}
\hline & \multicolumn{3}{c}{$\begin{array}{c}\text { employment rates (15-64) } \\
\%\end{array}$} & \multicolumn{2}{c}{$\begin{array}{c}\text { EUROMOD/LFS ratio of } \\
\text { employment rates }\end{array}$} \\
year & LFS & EUROMOD & adjusted & unadjusted \\
\hline 2009 & 60.8 & 59.5 & 59.5 & 0.98 & 0.98 \\
\hline 2010 & 59.1 & 57.9 & 59.5 & 0.98 & 1.01 \\
\hline 2011 & 55.1 & 54.1 & 59.5 & 0.98 & 1.08 \\
\hline 2012 & 50.8 & 49.8 & 59.5 & 0.98 & 1.17 \\
\hline 2013 & 48.8 & 47.9 & 59.5 & 0.98 & 1.22 \\
\hline 2014 & 49.4 & 48.5 & 59.5 & 0.98 & 1.20 \\
\hline
\end{tabular}

Source: Labour Force Survey, EUROMOD. 